\title{
PENGARUH STRUKTUR MODAL, LIKUIDITAS DAN UKURAN PERUSAHAAN TERHADAP PROFITABILITAS PADA PERUSAHAAN PROPERTY DAN REAL ESTATE
}

\author{
Ni Wayan Pradnyanita Sukmayanti ${ }^{1}$ \\ Nyoman Triaryati ${ }^{2}$ \\ ${ }^{1,2}$ Fakultas Ekonomi dan Bisnis Universitas Udayana (Unud), Bali, Indonesia \\ E-mail: pradnyanitasukma@gmail.com
}

\begin{abstract}
ABSTRAK
Profitabilitas adalah kemampuan perusahaan dalam memperoleh laba dari modal yang diinvestasikan. Salah satu sektor yang profitabilitasnya berfluktuasi cukup tinggi serta mendukung pembangunan infrastruktur ialah property dan real estate. Fluktuasi profitabilitas melatarbelakangi penelitian ini yang bertujuan untuk mengetahui pengaruh struktur modal, likuiditas dan ukuran perusahaan terhadap profitabilitas pada perusahaan property dan real estate di Bursa Efek Indonesia periode 2014-2016. Sampel yang digunakan dalam penelitian ini berjumlah 36 perusahaan. Metode penentuan sampel yang digunakan dalam penelitian ini adalah metode purposive sampling. Teknik analisis data yang digunakan dalam penelitian ini adalah analisis linier berganda. Hasil dari penelitian ini adalah variabel struktur modal berpengaruh positif dan tidak signifikan terhadap profitabilitas. Likuiditas berpengaruh negatif dan signifikan terhadap profitabilitas. Ukuran perusahaan berpengaruh negatif dan signifikan terhadap profitabilitas.
\end{abstract}

Kata kunci: struktur modal, likuiditas, ukuran perusahaan, profitabilitas

\begin{abstract}
Profitability is the company's ability to earn profits from invested capital. One of the sectors whose profitability fluctuates considerably and supports infrastructure development is property and real estate. Profitability fluctuations underlying this study aims to determine the effect of capital structure, liquidity and firm size on profitability in property and real estate firms in Indonesia Stock Exchange period 2014-2016. The sample used in this study amounted to 36 companies. The sample determination method used in this study is purposive sampling method. The data analysis technique used in this study is multiple linear analysis. The result of this research is the variable of capital structure have positive and not significant effect to profitability. Liquidity has a negative and significant effect on profitability. Company size has a negative and significant effect on profitability.
\end{abstract}

Keywords: capital structure, liquidity, company size, profitability 


\section{PENDAHULUAN}

Perusahaan pada dasarnya memiliki tujuan yang ingin dicapai yaitu untuk memperoleh keuntungan. Tercapainya tujuan tersebut ditentukan oleh kinerja perusahaan yang nantinya dapat dijadikan sebagai dasar dalam pengambilan keputusan oleh pihak internal maupun pihak eksternal. Pada saat pendirian perusahaan, pada saat perusahaan berjalan normal, maupun pada saat perusahaan mengadakan perluasan usaha, permodalan dibutuhkan oleh perusahaan (Hilmi, 2010). Sumber pendanaan dapat berasal dari pendanaan sendiri oleh pemilik ataupun berasal dari pihak eksternal yang berupa utang. Penentuan sumber pendanaan dilakukan untuk memperoleh keuntungan yang menjadi tujuan awal pendirian sebuah perusahaan (Nurcahyani, 2014). Sumber daya utamanya adalah modal sendiri yang diinvestasikan dalam aset perusahaan, seperti aset lancar, aset tetap, dan aset lainnya (Pontoh dan Ilat, 2013).

Persaingan dalam dunia usaha membuat setiap perusahaan berusaha untuk dapat lebih kompetitif agar tidak kalah bersaing dengan perusahaan lainnya. Perusahaan harus mampu mengelola keuangannya dengan baik, artinya kebijakan pengelolaan keuangan harus dapat menjamin keberlangsungan usaha perusahaan. Tujuan dari didirikannya perusahaan adalah untuk memperoleh keuntungan dan mempertahankan eksistensi perusahaan, dengan cara meningkatkan seluruh aktivitas perusahaan dan mengoptimalkan sumber daya yang dimiliki agar perusahaan mencapai laba yang maksimal (Dwiyanthi dan Sudiartha, 2017). Untuk mengukur efisiensi aktivitas suatu perusahaan dalam memperoleh laba dapat diukur dengan menggunakan rasio profitabilitas. 
Ni Wayan Pradnyanita Sukmayanti. Pengaruh Struktur Modal...

Perusahaan memiliki keberlangsungan hidup jangka panjang dan kesuksesan yang umumnya dianggap sebagai prasyarat penting untuk perusahaan yang disebut profitabilitas. Profitabilitas berpengaruh terhadap pertumbuhan ekonomi, lapangan kerja, inovasi, dan perubahan teknologi. Namun, karena persaingan yang semakin ketat, peningkatan efisiensi, dan tekanan harga, perusahaan mengalami kesulitan yang lebih besar untuk mencapai profitabilitas yang dibutuhkan (Yazdanfar, 2013).

Profitabilitas merupakan suatu kemampuan perusahaan untuk mewujudkan suatu keuntungan bagi perusahaan atau merupakan suatu pengukuran akan efektivitas pengelolaan perusahaan dalam mengelola manjemennya (Wiagustini, 2010: 76). Pengukuran profitabilitas dilakukan dengan menggunakan berbagai alat ukur dengan kinerjanya yang berbeda-beda antara satu penelitian dengan penelitian lainnya (Hafsah dan Sari, 2015). Profitabilitas suatu perusahaan dapat diukur dengan menghubungkan antara keuntungan atau laba yang diperoleh dari kegiatan pokok perusahaan dengan kekayaan atau asset yang dimiliki untuk menghasilkan keuntungan perusahaan (operating asset). Pendekatan ini dapat mengukur proses pembagian keuntungan secara finansial (Fareed et al., 2016). Rasio profitabilitas yang tinggi menunjukkan bahwa perusahaan memiliki keuntungan yang baik (Safitri dkk., 2014).

Menurut penelitian terdahulu yang dilakukan Astuti et al.(2015), pada perusahaan go public yang menjadi 100 perusahaan terbaik versi majalah Fortune Indonesia periode tahun 2010-2012 menemukan bahwa profitabilitas dipengaruhi secara positif signifikan oleh struktur modal. Penelitian yang dilakukan oleh 
Dwiyanthi dan Sudiartha (2017) pada perusahaan manufaktur sektor industri barang konsumsi menemukan bahwa profitabilitas dipengaruhi secara negatif dan signifikan oleh likuiditas khususnya current ratio. Penelitian yang dilakukan Purba dan Yadnya (2015) menemukan bahwa profitabilitas dipengaruhi secara positif signifikan oleh ukuran perusahaan.

Banyak faktor yang dapat mempengaruhi profitabilitas. Faktor yang mempengaruhi profitabilitas yakni likuiditas, manajemen aset, dan utang pada hasil operasi (Brigham dan Huston, 2010: 146). Menurut Harahap(2008: 305) profitabilitas menggambarkan kemampuan perusahaan mendapatkan labamelalui semua kemampuandansumberyangadasepertikegiatanpenjualan,kas,modal jumlahkaryawan,jumlahcabang danyang sebagainya.Modaltersebutterdiridari moda sendiri maupun asing yang ketika dibandingkan akan mampu menggambarkanstruktur modaldariperusahaan.Modaltersebutterdiridari modal sendiri maupunasing yang ketika dibandingkan akan mampu menggambarkanstruktur modaldariperusahaan.Besar kecilnyaprofitabilitas perusahaanjugadipengaruhiolehukuranperusahaanyangmenurutHarahap(2008:305) dilihat dari jumlah karyawan dan banyaknyacabangperusahaan.

Faktor hasil penelitiannya modal kerja berpengaruh signifikan terhadap profitabilitas, sedangkan leverage dan likuiditas berpengaruh tidak signifikan. Secara bersama-sama besar kecilnya profitabilitas dipengaruhi oleh efisiensi modal kerja, likuiditas dan leverage (Wibowo dan Wartini, 2012). Menurut Rifai et al.(2013) faktor mempengaruhi profitabilitas yaitu ukuran perusahaan, struktur modal, dan pertumbuhan perusahaan. Dari hasil penelitiannya ukuran perusahaan 
dan struktur modal berpengaruh signifikan, sedangkan pertumbuhan perusahaan berpengaruh tidak signifikan.

Faktor lainnya yang dapat mempengaruhi profitabilitas, yaitu modal kerja, likuiditas, aktivitas, dan ukuran perusahaan. Dari hasil penelitiannya modal kerja, aktivitas, ukuran perusahaan berpengaruh signifikan terhadap profitabilitas, sedangkan likuiditas berpngauh tidak signifikan terhdap profitabilitas (Ambarwati et al., 2015). Menurut Novita dan Sofie (2015) ada dua variabel yang mempengaruhi profitabilitas, yaitu struktur modal dan likuiditas. Dari penelitian ini struktur modal dan likuiditas berpengaruh signifikan terhadap profitabilitas.

Berdasarkan kajian empiris diatas ditemukan adanya perbedaan faktor yang mempengaruhi profitabilitas. Dalam variabel independent diatas dipilih menggunakan tiga faktor yang akan diteliti kembali untuk mengetahui apakah faktor tersebut mempengaruhi profitabilitas pada perusahaan property dan real estate di BEI periode 2014-2016. Faktor yang dipilih yaitu struktur modal, likuiditas dan ukuran perusahaan. Faktor pertama yaitu struktur modal dipilih karena struktur modal digunakan oleh perusahaan untuk menentukan sumber dana yang digunakan untuk membiayai kegiatan operasional, pengembangan usaha atau pendirian usaha baru. Sumber dana berasal dari modal sendiri atau modal asing yang nantinya akan digunakan oleh perusahaan untuk memperoleh profitabilitas. Faktor kedua yaitu likuiditas dipilih karena menunjukkan kemampuan perusahaan dalam memenuhi kewajiban atau membayar utang jangka pendeknya. Likuiditas mempunyai hubungan erat dengan profitabilitas, karena likuiditas menunjukkan tingkat ketersediaan modal kerja yang dibutuhkan untuk 
menjalankan kegiatan operasional perusahaan. Likuiditas yang dikelola dengan baik akan menyebabkan perolehan profitabilitas meningkat dan sebaliknya likuiditas yang tidak dimanfaatkan dengan baik akan menyebabkan profitabilitas menurun. Faktor ketiga yaitu ukuran perusahaan dipilih karena ukuran perusahaan merupakan suatu indikator yang dapat menunjukkan kondisi perusahaan yang dilihat dari gambaran besar kecilnya suatu perusahaan yang ditunjukkan oleh total aktiva, jumlah penjualan, rata-rata tingkat penjualan dan rata-rata total aktiva. Ukuran perusahaan yang diukur dengan asset perusahaan menunjukkan seberapa besar harta yang dimiliki perusahaan.

Addae et al. (2013) menyatakan bahwa struktur modal adalah sumber komposisi dana yang dikelola oleh perusahaan dalam menjalankan aktivitas bisnis usahanya untuk mendapatkan tingkat profitabilitas. Struktur modal yang optimal mempertimbangkan beberapa faktor antara lain pajak, biaya keagenan (agency costs) dan biaya kesulitan keuangan (financial distress), ketika beban biaya yang diakibatkan oleh penggunaan utang semakin besar, yang berarti bahwa terdapat trade-off biayadan manfaat atas penggunaan hutang (Sartono, 2010: 225 dalam Yani, 2016).

Trade off theory adalah teori yang menjelaskan keseimbangan antara manfaat dan pengorbanan yang ditimbulkan dari akibat penggunaan utang. Penggunaan utang dalam sumber pendanaan mempunyai manfaat, seperti dapat mengurangi jumlah pembayaran pajak karena beban bunga tetap yang ditimbulkan dari utang berbeda dengan pembayaran deviden yang tidak dapat mengurangi pembayaran pajak (Sibuea, 2012). Pengurangan pajak dilakukan 
Ni Wayan Pradnyanita Sukmayanti. Pengaruh Struktur Modal...

untuk kepentingan perusahaan dan pembayaran utang menguntungkan penerapan utang (Rasian dan Kim, 2011). Penggunaan utang dalam suatu perusahaan akan menaikkan laba, karena adanya kenaikan pajak yang merupakan pos deduksi terhadap biaya utang, namun pada titik tertentu penggunaan utang dapat menurunkan laba karena adanya pengaruh biaya kepailitan dan biaya bunga yang ditimbulkan dari adanya penggunaan utang.

Nurcahyani (2014) menyatakan debt to total assets ratio (DAR) merupakan salah satu rasio yang digunakan untuk mengukur tingkat solvabilitas perusahaan. Tingkat solvabilitas perusahaan merupakan kemampuan perusahaan untuk membayar kewajiban jangka panjangnya. Suatu perusahaan memiliki aktiva yang cukup untuk membayar utangnya dapat dikatakan perusahaan tersebut solvable. Semakin tinggi debt to asset ratio, menunjukkan semakin besar jumlah modal eksternal yang berasal dari pinjaman yang digunakan oleh perusahaan dalam menghasilkan keuntungan.

Menurut penelitian terdahulu yang dilakukan oleh Binangkit dan Raharjo (2014) pada perusahaan manufaktur yang terdaftar di Bursa Efek Indonesia menemukan adanya hubungan positif signifikan antara struktur modal terhadap profitabilitas. Penelitian yang dilakukan Margaretta (2010), Marusya dan Magantar (2016), Astuti et al.(2015), Efendi dan Wibowo (2017) menemukan bahwa adanya pengaruh positif signifikan antara struktur modal terhadap profitabilitas. Hasil temuan lainnya yang dilakukan oleh Niresh (2012) dan Shaputri dan Wibowo (2016) menyatakan bahwa struktur modal memiliki hubungan positif namun tidak signifikan. Penelitian tersebut menjadi tidak 
konsisten terhadap hasil penelitian dari Nurcahyani (2014), Fawzi dan Maroof (2012), Chechet dan Olayiwola (2014) menemukan terdapat hubungan negatif signifikan antara struktur modal terhadap profitabilitas perusahaan.

Sebagian besar perusahaan mengalami likuiditas yang sangat tidak stabil dengan arus kas yang sangat langka karena kondisi pasar kredit yang ketat dan penurunan permintaan (Enqvist et al., 2014). Menurut Kasmir (2012: 129) ketika jumlah aktiva lancar terlalu kecil maka akan menimbulkan illikuiditas, sedangkan apabila jumlah aktiva lancar terlalu besar akan berakibat timbulnya kas yang menganggur (idle fund), semua ini berpengaruh kepada jalannya operasi perusahaan. Selain masalah tersebut perusahaan juga dihadapkan pada masalah penentuan sumber dana. Likuiditas mempunyai hubungan yang erat dengan profitabilitas, karena likuiditas menujukkan tingkat ketersediaan modal kerja yang dibutuhkan dalam kegiatan operasional.

Menurut Horne dan Machowicz (2005: 313) pada saat perusahaan menetapkan aset yang besar, kemungkinan tingkat likuiditas akan aman, tetapi harapan untuk mendapatkan laba yang besar akan menurun yang kemudian akan berdampak pada profitabilitas perusahaan ataupun sebaliknya. Semakin tinggi likuiditas, maka semakin baik posisi perusahaan apabila dilihat dari kreditur karena terdapat kemungkinan yang lebih besar bahwa perusahaan akan dapat membayar kewajibannya tepat pada waktunya. Likuiditas yang tinggi dilihat dari segi sudut pemegang saham tidak selalu memberikan keuntungan karena berpeluang menimbulkan dana-dana yang menganggur yang sebenarnya dapat 
Ni Wayan Pradnyanita Sukmayanti. Pengaruh Struktur Modal...

digunakan untuk berinvestasi dalam proyek-proyek yang menguntungkan perusahaan.

Menurut penelitian terdahulu yaitu Wibowo dan Wartini (2012), Ambarwati dkk. (2015), Ratnasari dan Budiyanto (2016), menyatakan likuiditas berpengaruh positif namun tidak signifikan terhadap profitabilitas. Penelitian lainnya dikemukakan oleh Miadalyni (2013) dan Rengasamy (2014) mengenai pengaruh likuiditas terhadap profitabilitas menyatakan bahwa likuiditas berpengaruh positif signifikan terhadap profitabilitas. Hasil yang berbeda diperoleh dari hasil penelitian yang dilakukan Negasa (2016), Afriyanti (2011), Kartika (2014), menyatakan bahwa likuiditas berpengaruh negatif signifikan terhadap profitabilitas perusahaan. Semakin tinggi likuiditas perusahaan maka semakin baik kinerja perusahaan begitu pula sebaliknya. Perusahaan yang memiliki tingkat likuiditas yang tinggi mencerminkan ukuran perusahaan yang besar yang lebih berpeluang untuk mendapatkan berbagai macam dukungan dari pihak luar seperti kreditur.

Ukuran perusahaan memiliki perbedaan sehingga menimbulkan risiko usaha yang berbeda secara signifikan antara perusahaan besar dan perusahaan kecil. Semakin besar ukuran skala perusahaan membuat kreditur bisa merespon positif terhadap kenaikan nilai perusahaan (Sujoko dan Soebiantoro, 2007). Perusahaan dengan ukuran besar dianggap mempunyai risiko yang lebih kecil, karena perusahaan dengan ukuran besar dianggap lebih memiliki akses ke pasar modal sehingga lebih mudah untuk memperoleh tambahan dana yang kemudian dapat meningkatkan profitabilitas perusahaan. Tambahan dana yang berupa modal 
tersebut dimanfaatkan dengan baik untuk operasional perusahaan sehingga perusahaan dapat meningkatkan profitabilitas. Namun, pada perusahaan dengan ukuran kecil, para penanam modalakan lebih berhati-hati dalam membeli saham perusahaan karena adanya pemikiran bahwa perusahaan dengan ukuran kecil belum cukup memiliki prospek yang baik di masa depan.

Ukuran perusahaan dianggap mampu mempengaruhi kinerja keuangan perusahaan yang dilihat dari kualitas laporan keuangan yang disajikan (Fahmi, 2013: 2), karena ukuran perusahaan dilihat dari total aset yang dimiliki oleh perusahaan yang dapat dipergunakan untuk kegiatan operasional perusahaan atau dapat dilihat dari total penjualan perusahaan. Perusahaan dengan total aset yang besar, akan menyebabkan pihak manajemen lebih leluasa dalam mempergunakan aset yang ada diperusahaan tersebut, dan jika perusahaan memiliki total penjualan yang besar artinya perusahaan dapat mengelola persediaannya dengan baik yang dapat menghasilkan laba.

Beberapa penelitian yang mendukung pengaruh ukuran perusahaan terhadap profitabilitas pernah dilakukan dari hasil temuan oleh Sunarto dan Budi (2005), Purba dan Yadnya (2015), Usama (2014) yang menyatakan bahwa ukuran perusahaan memiliki pengaruh positif signifikan terhadap profitabilitas. Penelitian serupa juga dilakukan oleh Raheman et al. (2007) menemukan hubungan positif antara ukuran dan profitabilitas. Temuan penelitian lainnya oleh Amarjit dan Neil (2011) menemukan ukuran perusahaan meningkatkan profitabilitas perusahaan. Hasil yang berbeda di temukan pada penelitian yang dilakukan Ratnasari dan Budiyanto (2016) menyatakan ukuran perusahaan berpengaruh positif namun 
tidak signifikan terhadap profitabilitas pada perusahaan otomotif yang terdaftar di BEI. Hasil yang berbeda juga dikemukakan oleh Putri dkk. (2015), Mayasari (2012) dan Azlina (2009) menemukan bahwa ukuran perusahaan berpengaruh negatif signifikan terhadap profitabilitas.

Perusahaan dalam penelitian ini yang akan diteliti adalah perusahaan property dan real estate. Alasan diambilnya sektor property dan real estate dalam penelitian dikarenakan sektor ini merupakan salah satu sektor dengan fluktuasi cukup tinggi. Fluktuasi mengacu pada keadaan naik turunnya profitabilitas pada perusahaan property dan real estate. Sektor ini juga merupakan salah satu pendukung pembangunan infrastruktur dan memiliki peran penting dalam menunjang perekonomian. Sektor ini tidak hanya dibutuhkan untuk tempat tinggal, tetapi juga untuk investasi dan tempat berbisnis.

Profitabilitas memberikan gambaran seberapa efektif perusahaan beroperasi sehingga memberikan keuntungan bagi perusahaan. Profitabilitas suatu perusahaan dapat diukur dengan menghubungkan antara keuntungan atau laba yang diperoleh dari kegiatan pokok perusahaan dengan kekayaan atau aset yang dimiliki untuk menghasilkan keuntungan perusahaan (operating asset). Profitabilitas dalam kegiatan operasional perusahaan merupakan elemen penting dalam mempertahankan kelangsungan hidup perusahaan. Perusahaan yang memiliki kemampuan untuk memperoleh laba dengan memanfaatkan semua sumber daya perusahaan akan menyebabkan tujuan perusahaan tercapai. Laba merupakan hasil dari pendapatan oleh penjualan yang dikurangi dengan beban (Ratnasari dan Bidiyanto, 2016). 
Menurut Brigham dan Huston (2010: 146) faktor yang mempengaruhi profitabilitas yakni likuiditas, manajemen aset, dan utang pada hasil operasi. Profitabilitas dalam penelitian ini diproksikan dengan return on asset (ROA). ROA merupakan salah satu cara untuk menghitung kinerja keuangan perusahaan dengan membandingkan laba bersih dengan total aset perusahaan. Ini merupakan kemampuan dalam menghasilkan laba dengan memanfaatkan sumber daya yang ada (Carlo dan Daniele, 2016). ROA menunjukkan seberapa banyak perusahaan telah memperoleh hasil dari penggunaan sumber daya keuangan perusahaan. Sehingga penulis menggunakan ROA, hal ini dikarenakan ROA dalam analisis keuangan merupakan salah satu teknik yang bersifat menyeluruh dan lazim digunakan untuk mengukur tingkat efektivitas dari keseluruhan operasional perusahaan.

Keputusan pendanaan mengindikasikan bagaimana perusahaan membiayai kegiatan operasionalnya atau bagaimana perusahaan membiayai aktivanya. Pada keputusan pendanaan menyangkut dengan struktur keuangan perusahaan, dimana struktur keuangan perusahaan merupakan komposisi dari keputusan pendanaan yang meliputi hutang jangka pendek, hutang jangka panjang dan modal sendiri (Mardiyati et al., 2015). Keputusan pendanaan meliputi: pertama, berkaitan dari mana dana perusahaan dipenuhi dan kedua, berkaitan dengan analisis biaya dana atau modal yang dipergunakan perusahaan (Wiagustini, 2014: 234). Terdapat beberapa teori tentang pendanaan hutang, yaitu:

Pecking Order Theory dimana para manajer pertama kali menetapkan suatu urutan keputusan pendanaan yang akan dipilih untuk digunakan, seperti laba 
Ni Wayan Pradnyanita Sukmayanti. Pengaruh Struktur Modal...

ditahan, hutang dan penerbitan saham sebagai pemilihan terakhir. Pecking Order Theory menjelaskan perusahaan dengan profitabilitas yang tinggi umumnya menggunakan utang dalam jumlah sedikit, karena perusahaan tidak akan melakukan peminjaman jika tidak diperlukan. Perusahaan yang kurang profitable akan cenderung menggunakan utang yang lebih besar disebabkan karena dana internal tidak cukup untuk membiayai investasi perusahaan. Bagi perusahaan kecil utang merupakan sumber pendanaan yang lebih diminati

Trade Off Theory menyatakan bahwa perusahaan manyeimbangkan manfaat dari pendanaan dengan hutang dengan suku bunga dan biaya kebangkrutan yang lebih tinggi. Trade-off theory memprediksi perusahaan akan memilih utang sebagai sumber pendanaan apabila manfaat dari penambahan utang masih lebih besar dibandingkan dengan kerugiannya. Pada teori ini menjelaskan bahwa semakin tinggi perusahaan melakukan pendanaan menggunakan hutang maka semakin besar pula resiko mereka untuk mengalami kesulitan keuangan karena membayar bunga tetap yang terlalu besar bagi para debtholder. Teori ini menyatakan bahwa penggunaan hutang jangka panjang hanya dilakukan ketika pendanaan dengan laba ditahan dan hutang jangka panjang sudah tidak mencukupi, karena dalam packing order theory perusahaan disarankan memilih pendanaan yang paling aman terlebih dahulu yaitu laba ditahan dan hutang jangka pendek, dan bila pendanaan dari laba ditahan dan hutang jangka pendek sudah tidak mencukupi maka penggunaan hutang jangka panjang, dan saham baru sebagai pilihan terakhir (Brigham dan Ehrhardt, 2011: 616). 
Teori struktur modal (Capital structure theory) pada teori ini berpendapat bahwa dengan asumsi tidak ada pajak, bankruptcy cost, tidak adanya informasi asimetris antara pihak manajemen dengan para pemegang saham, dan pasar terlibat dalam kondisi yang efisien, maka value yang bisa diraih oleh perusahaan tidak terkait dengan bagaimana perusahaan melakukan strategi pendanaan.

Keputusan struktur modal yang efektif akan dapat merendahkan biaya modal yang akhirnya akan meningkatkan profitabilitas perusahaan. Pemenuhan modal kerja yang tepat akan menyebabkan perusahaan dapat berkembang dengan baik. Pengelolaan yang efektif dan efisien serta produktif akan sangat berpengaruh terhadap kinerja perusahaan. Penilaian kinerja bagi pihak manajemen perusahaan akan sangat mempengaruhi dalam penyusunan rencana usaha perusahaan yang akan diambil untuk masa yang akan datang demi kelangsungan hidup perusahaan (Marusya dan Magantar, 2016).

Menurut trade-off theory yang diungkapkan oleh Myers, perusahaan akan berhutang sampai pada tingkat utang tertentu, dimana penghematan pajak (tax shields) dari tambahan hutang sama dengan biaya kesulitan keuangan (financial distress) merupakan biaya kebangkrutan (bankruptcy costs) yang meningkat akibat dari turunnya kredibilitas suatu perusahaan. Trade-off theory menujukkan penggunaan utang bermanfaat bagi perusahaan baik berupa hutang jangka panjang maupun hutang jangka pendek. Jika perusahaan mampu memenuhi kewajibannya ini menujukkan perusahaan tersebut likuiditas dan jika perusahaan tidak mampu memenuhi kewajibannya maka perusahaan tersebut likuid. 
Menurut Fahmi (2013: 2) semakin baik kualitas laporan keuangan yang disajikan maka akan semakin menyakinkan pihak eksternal dalam melihat kinerja keuangan perusahaan tersebut, yang otomatis tentunya pihak-pihak yang berhubungan dengan perusahaan akan merasa puas dalam berbagai urusan dengan perusahaan. Perusahaan yang lebih besar memiliki akses yang lebih besar untuk mendapat sumber pendanaan dari berbagai sumber sehingga untuk memperoleh pinjaman dari kreditur akan lebih mudah karena perusahaan dengan ukuran besar memiliki profitabilitas lebih besar untuk memenangkan persaingan atau bertahan dalam industri. Semakin besar ukuran suatu perusahaan, maka kecenderungan menggunakan modal asing juga semakin besar. Perusahaan besar membutuhkan dana yang besar pula untuk menunjang operasionalnya, dan salah satu alternatif pemenuhannya adalah dengan modal asing apabila modal sendiri tidak mencukupi (Halim, 2007: 42). Dana eksternal yang berupa hutang dalam jumlah besar sehingga membantu kegiatan operasional perusahaan dan menyebabkan produktivitas perusahaan meningkat sehingga profitabilitas perusahaan akan meningkat pula.

Likuiditas merupakan kemampuan perusahaan untuk membayar kewajiban finansial jangka pendek tepat pada waktunya. Likuiditas perusahaan ditunjukkan oleh besar kecilnya aktiva lancar yaitu aktiva yang mudah diubah untuk menjadi kas yang meliputi kas, surat berharga, piutang, persediaan. Rasio likuiditas diukur menggunakan current ratio. Current ratio (CR) merupakan sebuah rasio likuiditas yang menggambarkan sampai sejauh apa kewajiban lancar ditutupi oleh aset lancar (Brigham, 2012: 134). Perusahaan yang hanya mengejar keuntungan tanpa 
memperhatikan likuiditas mengakibatkan perusahaan kurang mampu membayar kewajibannya sewaktu-waktu (Wiagustini, 2010: 61). Aset lancar merupakan aset yang dapat digunakan oleh perusahaan untuk memenuhi kewajiban jangka pendeknya (Khatik dan Titto, 2015). Menurut Riyanto (2010: 28), current ratio merupakan perbandingan antara aktiva lancar dengan utang lancar, maka setiap transaksi yang mengakibatkan perubahan jumlah aktiva lancar atau utang lancar baik masing-masing atau kedua-duanya, akan dapat menyebabkan perubahan current ratio, yang berarti akan menyebabkan perubahan tingkat likuiditas.

Semakin tinggi CR berarti semakin besar kemampuan perusahaan untuk memenuhi kewajiban finansial jangka pendek yang dibayar tepat waktu (Sartono, 2014: 122). Hal ini berlaku apabila pimpinan perusahaan menguasai pos-pos modal kerja dengan semestinya. Pada umumnya current ratio yang rendah lebih banyak mengandung resiko dari pada current ratio yang tinggi. Current ratio yang rendah menunjukkan pimpinan perusahaan menggunakan aktiva lancar sangat efektif apabila saldo disesuaikan dengan kebutuhan minimum dan perputaran piutang dari persediaan ditingkatkan sampai pada tingkat maksimum. Jumlah kas yang diperlukan tergantung dari besarnya perusahaan dan terutama dari jumlah uang yang diperlukan untuk membayar utang lancar, berbagai biaya rutin dan pengeluaran darurat (Tunggal, 2005: 157).

Munawir (2004: 72) menyatakan current ratio menunjukkan tingkat keamanan (margin of safety) kreditor jangka pendek atau kemampuan perusahaan untuk membayar utang-utang tersebut. Tetapi suatu perusahaan dengan current ratio yang tinggi belum tentu menjamin utang perusahaan yang sudah jatuh tempo 
dapat dibayarkan karena proporsi atau distribusi dari aktiva lancar yang tidak menguntungkan, misalnya jumlah persediaan yang relatif tinggi dibandingkan taksiran tingkat penjualan yang akan datang sehingga tingkat perputaran persediaan yang besar akan menjadi sulit untuk ditagih.

Penelitian yang dilakukan Margaretta (2010), Astuti et al. (2015), Marusya dan Magantar (2016), serta penelitian yang dilakukan Efendi dan Wibowo (2017), untuk menguji pengaruh struktur modal terhadap profitabilitas, menyatakan struktur modal berpengaruh positif dan signifikan terhadap profitabilitas. Penelitian yang dilakukan oleh Binangkit dan Raharjo (2014) pada perusahaan manufaktur yang terdaftar di Bursa Efek Indonesia menemukan adanya hubungan positif signifikan antara struktur modal terhadap profitabilitas.

$\mathrm{H}_{1}$ : Struktur Modal berpengaruh positif signifikan terhadap profitabilitas.

Hasil penelitian yang dilakukan oleh Negasa (2016), Afriyanti (2011), serta Kartika (2014), menemukan bahwa likuiditas berpengaruh negatif signifikan terhadap profitabilitas. Penelitian lainnya yang dilakukan oleh Dwiyanthi dan Sudiartha (2016) menyatakan bahwa likuiditas berpengaruh negatif signifikan terhadap profitabilitas perusahaan. Hal ini berarti bahwa apabila likuiditas mengalami kenaikan maka akan menurunkan nilai profitabilitas sebaliknya apabila likuiditas mengalami penurunan makan akan menaikkan nilai profitabilitas.

$\mathrm{H}_{2}$ : Likuiditas berpengaruh negatif signifikan terhadap profitabilitas.

Hasil temuan yang dilakukan oleh Sunarto dan Budi (2009), Gill dan Mathur (2011), Yazdanfar dan Ohman (2014), serta Purba dan Yadnya (2015), 
menemukan hasil bahwa ukuran perusahaan berpengaruh positif signifikan terhadap profitabilitas.

$\mathrm{H}_{3}$ : Ukuran perusahaan berpengaruh positif signifikan terhadap profitabilitas.

\section{METODE PENELITIAN}

Penelitian ini dilakukan pada perusahaan property dan real estate di Bursa Efek Indonesia. Variabel bebas dalam penelitian ini yaitu $\mathrm{X}_{1}=$ Struktur Modal, $\mathrm{X}_{2}$ $=$ Likuiditas, dan $\mathrm{X}_{3}=$ Ukuran Perusahaan. Variabel terikat dalam penelitian ini yaitu $\mathrm{Y}=$ Profitabilitas. Populasi dalam penelitian ini adalah seluruh perusahaan property dan real estatedi Bursa Efek Indonesia periode 2014-2016 yang berjumlah 48 perusahaan. Sampel yang diambil menggunakan metode purposive sampling dalam penentuan sampelnya.

\section{Tabel 1.}

Proses Pemilihan Sampel

\begin{tabular}{lc}
\hline \multicolumn{1}{c}{ Keterangan } & Jumlah Perusahaan \\
\hline $\begin{array}{l}\text { Perusahaan property dan real } \\
\text { estate yang terdaftar di BEI } \\
\text { (populasi) }\end{array}$ & 48 \\
$\begin{array}{l}\text { Perusahaan property dan real } \\
\text { estate yang terdaftar di BEI } \\
\text { periode 2014-2016 diseleksi } \\
\text { berdasarkan purposive sampling } \\
\text { Total Sampel }\end{array}$ & \\
\hline
\end{tabular}

Sumber: Data diolah, 2018

Metode pengumpulan data yang digunakan dalam penelitian ini adalah metode observasi. Observasi yang dilakukan adalah observasi non-participant. Teknik analisis data yang digunakan untuk menguji bagaimana pengaruh struktur modal, likuiditas dan ukuran perusahaan terhadap profitabilitas pada perusahaan property dan real estate dengan teknik analisis linear berganda dengan bantuan program SPSS (Statistical Package for Social Science) 20.0. 


\section{HASIL PENELITIAN DAN PEMBAHASAN}

Analisis statistik deskriptif merupakan deskripsi data dari seluruh variabel yang diteliti. Hasil dari analisis statistik deskriptif memperlihatkan jumlah data yang digunakan dalam penelitian, nilai minimum, nilai maksimum, mean (ratarata), dan deviasi standar. Penelitian ini menggunakan variabel profitabilitas (ROA), struktur modal (DAR), likuiditas (CR), dan ukuran perusahaan. Hasil statistik deskriptif disajikan pada tabel 2 di bawah ini:

Tabel 2.

Hasil Analiss Statistik Deskriptif

\begin{tabular}{cccccc}
\hline & N & Minimum & Maximum & Mean & $\begin{array}{c}\text { Std. } \\
\text { Deviation }\end{array}$ \\
\hline N Valid & 108 & & & & \\
ROA (\%) & 108 & $-4,170$ & 17,550 & 4,32590 & 4,311518 \\
DAR (\%) & 108 & 3,490 & 65,640 & 37,60246 & 15,453942 \\
CR (\%) & 108 & 152,340 & 2866,760 & 385,17441 & 349,4310 \\
Ukuran (Ln) & 108 & 9,670 & 21,050 & 14,59292 & 2,148584 \\
\hline Sumber: Data diolah, 2018 & & &
\end{tabular}

Berdasarkan Tabel 2 menunjukkan bahwa jumlah data yang digunakan dalam penelitian ini berjumlah 108 data yang didapatkan dari 36 data laporan keuangan perusahaan dikalikan 3 tahun (2014-2016). Analisis deskriptif masingmasing variabel adalah variabel profitabilitas (ROA) memiliki nilai rata-rata sebesar 4,32590\% dan memiliki standar deviasi sebesar 4,311518\%. Nilai minimum sebesar $-4,170 \%$ dimiliki oleh Rista Bintang Mahkota Sejati Tbk pada tahun 2016 sedangkan nilai maksimum sebesar 17,550\% dimiliki oleh Agung Podomoro Land Tbk pada tahun 2014.

Variabel struktur modal (DAR) memiliki nilai rata-rata sebesar 37,60246\% dan memiliki standar deviasi sebesar $15,453942 \%$. Nilai minimum sebesar 3,490\% dimiliki oleh Rista Bintang Mahkota Sejati Tbk pada tahun 2016 
sedangkan nilai maksimum sebesar 65,640\% dimiliki oleh Cowell Development Tbk pada tahun 2016 .

Variabel likuiditas (CR) memiliki nilai rata-rata sebesar 385,17441\% dan memiliki standar deviasi sebesar 349,4310\%. Nilai minimum sebesar $152,340 \%$ dimiliki oleh Cowell Development Tbk pada tahun 2016 sedangkan nilai maksimum sebesar 28866,760\% dimiliki oleh Rista Bintang Mahkota Sejati Tbk pada tahun 2016 .

Variabel ukuran perusahaan memiliki nilai rata-rata sebesar 14,59292\% dan memiliki standar deviasi sebesar 2,148584\%. Nilai minimum sebesar 9,670\% dimiliki oleh Summarecon Agung Tbk pada tahun 2014 sedangkan nilai maksimum sebesar 21,050\% dimiliki oleh Gading Development Tbk pada tahun 2014

Analisis linear berganda digunakan untuk mengetahui arah dan besarnya pengaruh struktur modal, likuiditas dan ukuran perusahaan terhadap profitabilitas pada perusahaan property dan real estate yang terdaftar di Bursa Efek Indonesia periode 2014-2016.

Tabel 3.

Analisis Linear Berganda

\begin{tabular}{cccccc}
\hline Model & \multicolumn{2}{c}{$\begin{array}{c}\text { Unstandardized } \\
\text { Coefficients }\end{array}$} & $\begin{array}{c}\text { Standardized } \\
\text { coefficient } \\
\text { Beta }\end{array}$ & t & Sig. \\
\hline (Constant) & 11,853 & 3,933 & & 3,014 &, 003 \\
DAR (\%) &, 008 &, 039 &, 030 &, 213 &, 832 \\
CR (\%) &,- 004 &, 002 &,- 288 & $-2,121$ &, 036 \\
Ukuran (Ln) &,- 443 &, 192 &,- 221 & $-2,312$ &, 023 \\
\hline
\end{tabular}

Sumber: Data diolah, 2018

Berdasarkan Tabel 3 dapat diperoleh persamaan regresi linear berganda sebagai berikut. 


$$
Y=11,853+0,008 X_{1}-0,004 X_{2}-0,443 X_{3}
$$

Keterangan:

$$
\begin{array}{ll}
\mathrm{Y} & =\text { Profitabilitas } \\
\mathrm{a} & =\text { Konstanta } \\
\beta_{1}-\beta_{3} & =\text { Koefisien regresi masing-masing Xi } \\
\mathrm{X}_{1} & =\text { Struktur modal (DAR) } \\
\mathrm{X}_{2} & =\text { Likuiditas (CR) } \\
\mathrm{X}_{3} & =\text { Ukuran perusahaan }
\end{array}
$$

Berdasarkan Tabel 3 dapat diketahui bahwa nilai sig. 0,832. Nilai sig.0,832 $>\alpha=0,05$ hal ini menujukkan $\mathrm{H}_{0}$ diterima dan $\mathrm{H}_{1}$ ditolak yang berarti bahwa struktur modal secara tidak signifikan berpengaruh terhadap profitabilitas. Koefisien struktur modal sebesar 0,008 menunjukkan adanya pengaruh positif antara struktur modal terhadap profitabilitas. Hasil tersebut mengindikasikan bahwa hipotesis 1 yang menyatakan bahwa struktur modal berpengaruh positif signifikan terhadap profitabilitas tidak diterima.

Hasil dalam penelitian ini menunjukkan bahwa struktur modal (DAR) tidak berpengaruh signifikan terhadap profitabilitas yang diukur dengan return on assets (ROA) pada perusahaan property dan real estateyang terdaftar di Bursa Efek Indonesia periode 2014-2016. Hasil penelitian tersebut menolak hipotesis pertama yang menyatakan struktur modal berpengaruh positif signifikan terhadap profitabilitas. Pada dasarnya perusahaan menginginkan struktur modal yang optimal yang merupakan kombinasi antara modal asing dengan modal sendiri sehinga memperoleh keuntungan (Sartono, 2008: 245). Tidak signifikan tersebut menunjukkan bahwa apabila struktur modal mengalami peningkatan maka hal itu tidak akan diikuti oleh peningkatan profitabilitas. Semakin tinggi struktur modal 
yang digunakan oleh perusahaan maka tingkat penggunaan dana untuk kinerja perusahaan juga semakin tinggi sehingga tidak akan mempengaruhi perolehan profitabilitas perusahaan. Hasil penelitian ini didukung oleh Niresh (2012), Shaputri dan Wibowo (2016), Wisnala dan Purbawangsa (2014) menyatakan bahwa struktur modal tidak berpengaruh signifikan terhadap profitabilitas.

Berdasarkan Tabel 3 dapat diketahui bahwa nila sig. 0,036. Nilai sig.0,036 < $\alpha=0,05$ hal ini menujukkan $\mathrm{H}_{0}$ ditolak dan $\mathrm{H}_{1}$ diterima yang berarti bahwa likuiditas secara signifikan berpengaruh terhadap profitabilitas. Koefisien likuiditas sebesar -0.004 menunjukkan adanya pengaruh negatif antara likuiditas terhadap profitabilitas. Hasil tersebut mengindikasikan bahwa hipotesis 2 yang menyatakan bahwa likuiditas berpengaruh negatif signifikan terhadap profitabilitas diterima.

Hasil dalam penelitian ini menunjukkan bahwa likuiditas (CR) berpengaruh negatif signifikan terhadap profitabilitas yang diukur dengan return on assets (ROA) pada perusahaan property dan real estateyang terdaftar di Bursa Efek Indonesia periode 2014-2016. Hasil penelitian tersebut mendukung hipotesis kedua yang menyatakan likuiditas berpengaruh negatif signifikan terhadap profitabilitas. Pengaruh negatif signifikan menunjukkan bahwa semakin rasio lancar, maka menunjukkan semakin besar kemampuan perusahaan untuk memenuhi kewajiban jangka pendeknya. Perusahaan akan menempatkan dana yang besar pada sisi aktiva lancar (Afrinda, 2013). Penempatan dana yang terlalu besar akan memberikan dua dampak yang berbeda yaitu likuiditas perusahaan semakin baik namun perusahaan kehilangan kesempatan untuk mendapatkan 
tambahan laba, karena dana yang seharusnya digunakan untuk investasi yang menguntungkan dicadangkan untuk memenuhi likuiditas pada perusahaan property dan real estate yang terdaftar di Bursa Efek Indonesia periode 20142016.

Berdasarkan Tabel 3 dapat diketahui bahwa nila sig. 0,023. Nilai sig.0,023< $\alpha=0,05$ hal ini menujukkan $\mathrm{H}_{0}$ ditolak dan $\mathrm{H}_{1}$ diterimayang berarti bahwa ukuran perusahaan secara signifikan berpengaruh terhadap profitabilitas. Koefisien ukuran perusahaan sebesar $-0,443$ menunjukkan adanya pengaruh negatif antara ukuran perusahaan terhadap profitabilitas. Hasil tersebut mengindikasikan bahwa hipotesis 3 yang menyatakan bahwa ukuran perusahaan berpengaruh positif signifikan terhadap profitabilitas tidak diterima.

Hasil dalam penelitian ini menunjukkan bahwa ukuran perusahaan berpengaruh negatif signifikan terhadap profitabilitas yang diukur dengan return on assets (ROA) pada perusahaan property dan real estateyang terdaftar di Bursa Efek Indonesia periode 2014-2016. Hasil penelitian tersebut menolak hipotesis ketiga yang menyatakan ukuran perusahaan berpengaruh positif signifikan terhadap profitabilitas. Hasil penelitian yang negatif menunjukkan bahwa apabila ukuran perusahaan mengalami peningkatan maka profitabilitas akan mengalami penurunan. Ukuran perusahaan merupakan gambaran kemampuan finansial perusahaan dalam suatu periode tertentu yang ditunjukkan oleh total aktiva (Masfufah, 2016). Semakin besar total aktiva perusahaan maka semakin besar pula ukuran suatu perusahaan. Perusahaan dengan ukuran besar akan lebih mudah untuk melakukan utang dalam jumlah yang besar sehingga penggunaan utang 
yang akan menjadi modal usaha dapat membantu kegiatan operasional perusahaan. Tingginya penggunaan utang dengan rendahnya tingkat pengembalian atas modal yang menyebabkan berkurangnya profitabilitas.

Peningkatan ukuran perusahaan dapat menurunkan profitabilitas perusahaan. Aktivitas tersebut akanmencerminkan penambahan aset yang tidak diimbangi dengan kemampuan perusahaan dalam mengelola aset untuk meningkatkan profitabilitas perusahaan. Hasil penelitian ini didukung oleh Wulandari (2017), Meidiyustiani (2016), Siregar dan Utama (2005), Putri dkk. (2015), Mayasari (2012) dan Azlina (2009) yang menemukan bahwa ukuran perusahaan berpengaruh negatif signifikan terhadap profitabilitas.

Bersadarkan pembahasan hasil penelitian, adapun implikasi dari hasil penelitian ini adalah struktur modal diukur dengan debt to asset ratio. Hasil penelitian ini menunjukkan bahwa struktur modal memiliki pengaruh tidak signifikan terhadap profitabilitas. Struktur modal yang semakin tinggi digunakan oleh perusahaan maka akan menyebabkan tingkat penggunaan dana untuk menunjang kinerja perusahaan juga semakin tinggi. Dengan kata lain, perusahaan property dan real estate tidak dapat meningkatkan profitabilitas perusahaan hanya dengan mengubah proporsi debt dan equity yang digunakan untuk membiayai perusahaan. Sesuai dengan trade off theory yang menyatakan bahwa semakin tinggi perusahaan melakukan pendanaan menggunakan utang maka semakin besar pula resiko mereka untuk mengalami kesulitan keuangan karena membayar bunga tetap yang terlalu besar bagi para debtholder, sehingga kesulitan keuangan tersebut nantinya tidak dapat meningkatkan profitabilitas perusahaan. 
Likuiditas perusahaan diukur dengan current ratio. Hasil penelitian ini menunjukkan bahwa likuiditas berpengaruh negatif signifikan terhadap profitabilitas pada perusahaan property dan real estate yang terdaftar di BEI periode 2014-2016. Menurut Horne dan Machowicz (2005: 313) dalam bukunya prinsip-prinsip manajemen keuangan, kemampuan memperoleh laba berbanding terbalik dengan likuiditas. Kemampuan yang berbanding terbalik tersebut akan menjadi permasalahan dalam perusahaan ketika perusahaan menetapkan aset yang besar namun tidak digunakan secara optimal untuk memperoleh tingkat profitabilitas maka menyebabkan profitabilitas pada perusahaan menurun. Perusahaan tidak dapat memenuhi kebutuhan jangka pendek sepenuhnya atau lebih kecil karena aktiva yang dimiliki sebagian digunakan untuk kegiatan operasional perusahaan.

Ukuran perusahaan merupakan gambaran kemampuan finansial suatu perusahaan dalam satu periode. Dalam hasil penelitian dinyatakan bahwa ukuran perusahaan berpengaruh negatif signifikan terhadap profitabilitas. Hal ini menunjukkan bahwajika aset perusahaan naik maka profitabilitas akan menurun. Hal tersebut juga menunjukan bahwa penambahan aset tidak diimbangi dengan kemampuan perusahaan dalam mengelola aset untuk meningkatkan profitabilitas perusahaan. Sehingga diharapkan perusahaan property dan real estatedapat mempertahankan aset yang dimiliki dan dapat memanfaatkan aset lebih produktif lagi dengan harapan profitabilitas yang akan di peroleh nantinya tetap stabil ataupun meningkat. 


\section{SIMPULAN DAN SARAN}

Berdasakan hasil dari penelitian yang sudah dilakukan, maka dapat disimpulkan bahwa struktur modal berpengaruh tidak signifikan terhadap profitabilitas pada Perusahaan Property dan Real Estate yang terdaftar di Bursa Efek Indonesia periode 2014-2016. Maka dari itu, struktur modal yang meninkat tersebut mencerminkan tidak terjadinya peningkatan dalam profitabilitas.

Likuiditas berpengaruh negatif signifikan terhadap profitabilitas pada Perusahaan Property dan Real Estate yang terdaftar di Bursa Efek Indonesia periode 2014-2016. Hasil tersebut menunjukkan bahwa semakin meningkatnya likuiditas maka akan menurunkan profitabilitas karena tidak adanya pemanfaatan kas yang maksimal oleh perusahaan untuk modal usaha, pembangunan usaha baru atau perluasan usaha.

Ukuran perusahaan berpengaruh negatif signifikan terhadap profitabilitas pada Perusahaan Property dan Real Estate yang terdaftar di Bursa Efek Indonesia periode 2014-2016. Hal tersebut menunjukkan bahwa perusahaan terus meningkatkan jumlah asetnya tanpa pengelolaan yang baik tidakakan diikuti dengan peningkatan profitabilitas.

Adapun saran yang dapat peneliti berikan bagi peneliti selanjutnya maupun bagi manajemen perusahaan adalah bagi peneliti selanjutnya dapat mengembangkan hasil penelitian dengan menggunakan variabel lain yang dapat mempengaruhi profitabilitas dan dapat menggunakan objek perusahaan lain, menambah periode penelitian yang lebih lama, serta dapat menggunakan teknik analisis yang berbeda. 
Bagi perusahaan khususnya pada perusahaan property dan real estate disarankan untuk mempertimbangkan sumber daya yang dimiliki perusahaan baik berupa modal sendiri selain hutang yang dimanfaatkan untuk memperoleh profitabilitas. Dengan adanya pemanfaatan modal yang baik maka profitabilitas yang diperoleh juga meningkat. Keputusan pendanaanyang dilakukan oleh perusahaan haruslah tepat agar tujuan perusahaan dapat tercapai sesuai dengan harapan.

\section{REFERENSI}

Afrinda, Nidya. (2013). Analisis Pengaruh Likuiditas dan Solvabilitas Terhadap Profitabilitas Pada Perusahaan Makanan dan Minuman yang Terdaftar di Bursa Efek Indonesia. Jurnal Fakultas Ekonomi Universitas Sriwijaya.4(2): 30-42

Ambarwati, Novi Sagita; Gede Adi Yuniarta dan Ni Kadek Sinarwati. (2015). Pengaruh Modal Kerja, Likuiditas, Aktivitas dan Ukuran Perusahaan Terhadap Profitabilitas Pada Perusahaan Manufaktur Yang Terdaftar Di Bursa Efek Indonesia. E-Journal $S 1$ Ak Universitas Pendidikan Ganesha, 3(1): 12-27.

Astuti, Kurniasih Dwi; Wulan Retnowati dan Ahmad Rosyid. (2015). Pengaruh Struktur Modal Terhadap Profitabilitas (Studi Pada Perusahaan Go Publik yang Menjadi 100 Perusahaan Terbaik Versi Majalah Fortune Indonesia Periode Tahun 2010-2012. Jurnal Akuntansi, 2(1): 49-60.

Binangkit, A. Bagas dan Sugeng Raharjo. (2014). Pengaruh Struktur Modal Terhadap Kinerja Perusahaan dan Harga Saham Pada Perusahaan Manufaktur di Bursa Efek Indonesia. Jurnal Aktual edisi Pebruari 2014, 1(2): 24-34.

Brigham, Eugene F dan Joel F Huston. (2010). Dasar-Dasar Manajemen Keuangan Essentials of Financial Management. Edisi 11. Jakarta: Salemba Empat.

Brigham. (2012). Dasar-Dasar Manajemen Keuangan. Edisi kesepuluh. Jakarta: Salemba Empat.

Chechet, Ishaya Luka and Abduljeleel Badmus Olayiwola. (2014). Capital Structure and Profitability of Nigerian Quoted Firms: The Agency Cost 
Theory Prespective. American International Journal of Social Science, 3(1): 139-158.

Dwiyanthi, Novia dan Sudiartha Merta. (2017). Pengaruh Likuiditas dan Perputaran Modal Kerja terhadap Profitabilitas pada Perusahaan Manufaktur Sektor Industri Barang Konsumsi. E-Jurnal Manajemen Unud, 6(9): 4829-4856.

Efendi, Azzalia Feronicha Wianta dan Seto Sulaksono Adi Wibowo. (2017). Pengaruh Debt to Equity Ratio (DER) dan Debt to Asset Ratio (DAR) Terhadap Kinerja Perusahaan di Sektor Keuangan yang Terdaftar di Bursa Efek Indonesia. Journal of Applied Managerial Accounting, 1(2): 89-95.

Fahmi, Irham. (2016). Pengantar Manajemen Keuangan Teori dan Soal Jawab. Bandung: Alfabeta.

Fareed, Zeeshan; ZahidAli; Farrukh Shahzad; Muhammad Imran Nazir and Assad Ullah. (2016). Determinants Of Profitability: Evidence From Power And Energy Sector. Studia Ubb Oeconomica, 61(3): 59-78.

Gill, Amarjit and Mathur Neil. (2011). The Impact of Board Size, CEO Duality, and Corporate Liquidity on the Profitability of Canadian Service Firms. Journal of Applied Finance \& Banking, 1(3): 83-95.

Hafsah dan Sri Sutra Sari. (2015). Pengaruh Struktur Modal Terhadap Kinerja Keuangan pada Perusahaan property dan real estate yang terdaftar di BEI. Jurnal Riset Akutansi dan Bisnis. 15(1): 52-64.

Halim, A. (2007). Akuntansi Keuangan Daerah. Edisi Ketiga. Salemba. Jakarta. Haron,

RazaliandNomranNajiMansour.(2015).DeterminantsofWorkingCapitalMa nagementBefore,During,AndAfterTheGlobalFinancialCrisisof2008:

EvidenceFrom Malaysia.The Journal OfDeveloping Areas,SpecialIssueon Kuala Lumpur,50(5): 461-469.

Kasmir. (2012). Analisis Laporan Keuangan. Jakarta. PT Raja Grafindo Persada.

Khatik and Varghese Titto. (2015).Impact of Working Capital Management on Firm Profitability: An Empirical Study of ITC Ltd. International Journal of Information, Business and Management, 7(4): 284-306.

Mardiyati, Um; Gatot Nazir Ahmad dan Muhammad Abrar. (2015). Pengaruh Keputusan Investasi, Keputusan Pendanaan, Ukuran Perusahaan dan Profitabilitas Terhadap Nilai Perusahaan Pada Sektor Manufaktur Barang 
Konsumsi Yang Terdaftar di Bursa Efek Indonesia Periode 2010-2013. Jurnal Riset Manajemen Sains Indonesia, 6(1): 417-439.

Marusya, Pontororing dan Mariam Magantar. (2016). Pengaruh Struktur Modal Terhadap Profitabilitas Pada Perusahaan Tobacco Manufacturers yang Terdaftar di BEI Periode 2008-2015. Jurnal Berkala Ilmiah Efisiensi, 16(03): 484-492.

Meidiyustiani, Rinny. (2016). Pengaruh Modal Kerja, Ukuran Perusahaan, Pertumbuhan Penjualan dan Likuiditas Terhadap Profitabilitas Pada Perusahaan Manufaktur Sektor Industri Barang Konsumsi yang Terdaftar di Bursa Efek Indonesia (BEI) Periode Tahun 2010-2014. Jurnal Akuntansi dan Keuangan FE Universitas Budi Luhur, 5(2): 161-179.

Migliardo, Carlo and Schilirò Daniele. (2016).Mid-Sized Italian Manufacturing Firms:APanelDataAnalysisonProfitability.JournalofAdvancedStudies in Finance, VIIIssue2(14): 129-145.

Negasa, Tariku. (2016).The Effect of Capital Structure on Firms Profitability (Evidenced from Ethiopian).Department of Accounting \& Finance, Wollega University, Ethiopia,13(1): 1-9.

Niresh, J. Aloy. (2012). Trade-Off Between Liquidity \& Profitability: A Study Of Selected Manufacturing Firms In Sri Lanka. International Refereed Research Journal, III Issue 4(2): 34-40.

Niresh, J Aloy. (2012). Capital Structure and Profitability in srilanka. Global Journal of Management and Business Research, 12(13): 89-90.

Novita. A. N. dan Sofie. (2015). Pengaruh Struktur Modal Dan Likuiditas Terhadap Profitabilitas. e-Journal Akuntansi Trisakti 2(1) : 13-28.

Pontoh, Wingston and Ventje Ilat. (2013). Determinant Capital Structure and Profitability Impact (Study of Listed Company in Indonesian Stock Exchange). Research Journal of Finance and Accounting, 4(15): 43-49.

Purba, Ida Bagus Gde Indra Wedhana dan Putu Yadnya. (2015). Pengaruh Ukuran Perusahaan dan Leverage terhadap Profitability dan Pengungkapan Corporate Social Responsibility. E-Jurnal Manajemen Unud, 4(8): 24282443.

Purwohandoko.(2017).TheInfluenceofFirm'sSize,Growth,andProfitability on FirmValuewithCapitalStructureastheMediator:AStudy onthe Agricultural FirmsListed in theIndonesian Stock Exchange.International Journal of Economics and Finance, 9(8): 103-110. 
Putri, Novita Sari; Safitri Ervita; Wijaya Trisnadi. (2015). Pengaruh Leverage, Ukuran Perusahaan, Perputaran Modal Kerja dan Likuiditas terhadap Profitabilitas. Jurnal Jurusan Manajemen, STIE MDP, 7(3): 1-15.

R,KajananthanandS, Achchuthan.(2013).LiquidityandCapitalStructure:Special referencetoSriLanka TelecomPlc. AdvancesinManagement\& Applied Economics, 3(5): pp: 89-99.

Ratnasari, Linda dan Budiyanto. (2016). Pengaruh Leverage, Likuiditas, Ukuran Perusahaan terhadap Profitabilitas pada Perusahaan Otomotif di BEI. Jurnal Ilmu dan Riset Manajemen. 5(6): 1-15.

Rifai. M., R. Arifati., dan M. Magdalena. (2013). Pengaruh Ukuran Perusahaan, Struktur Modal dan Pertumbuhan Perusahaan Terhadap Profitabilitas Studi Pada Perusahaan Manufaktur Di Bei Tahun 2010-2012. Jurnal Akuntansi Universitas Pandanaran Semarang 2(1): 768-783.

Safitri, Nur Okyan; Handayani Siti Ragil and Nuzula Nila Firdausi. (2014). The Influence Of Capital Structure And Profitability On Firm Value (A Study in Retail Companies Listed in Indonesia Stock Exchange 2010-2013 period). Jurnal Administrasi Bisnis (JAB), 13(2): 1-19.

Sartono, Agus. (2014). Manajemen Keuangan Teori dan Aplikasi. Yogyakarta. BPFE-Yogyakarta.

Shaputri, Silvia Juni dan Seto Sulaksono Adi Wibowo. (2016). Pengaruh Struktur Modal Terhadap Kinerja Perusahaan Non Keuangan yang Terdaftar di BEI. Jurnal Akuntansi, Ekonomi dan Manajemen Bisnis, 4(2): 107-114.

Sunarto dan Agus Prasetyo Budi. (2009). Pengaruh Leverage, Ukuran dan Pertumbuhan Perusahaan Terhadap Profitabilitas. Telaah Manajemen Marlin. 6(1): 86-103.

Velnampy,TandJAloyNiresh.(2012).TheRelationshipbetweenCapitalStructure\&Pr ofitability.GlobalJournalofManagementandBusinessResearch,12(13):

OnlineISSN: 2249-4588 \&PrintISSN: 0975-5853.

Wiagustini, Ni Luh Putu. (2010). Dasar-dasar Manajemen Keuangan. Denpasar.Udayana University Press. . (2014). Manajemen Keuangan. Denpasar. Udayana University Press.

Wibowo, A. dan S. Wartini. (2012). Efisiensi Modal Kerja, Likuiditas dan Leverage Terhadap Profitabilitas Pada Perusahaan Manufaktur Di BEI. Jurnal Dinamika Manajemen, 3(1): 49-58. 
Wisnala, Vudha dan Ida Bagus Anom Purbawangsa. (2014). Pengaruh Struktur Modal Terhadap Profitabilitas Sebelum dan Setelah Krisis Global Pada Perusahaan Perbankan di Bursa Efek Indonesia. E-Jurnal Manajemen Universitas Udayana, 3(2):366-385.

Yani, Dyah Fitri. (2016). Hutang Jangka Panjang dan Profitabilitas di Bank Syariah: Studi Pada PT Bank Muamalat Indonesia. Jurnal Manajemen, Strategi Bisnis dan Kewirausahaan, 10(1): 52-63.

Yazdanfar,Darush and Ohman Peter. (2013). Profitability determinants among micro firms: evidence from Swedish data. International Journal of Managerial Finance, 9(2): 150-160.

Yazdanfar,Darush

and

Ohman

Peter.(2014).TheimpactofcashconversioncycleonfirmprofitabilityAn empiricalstudy basedonSwedishdata.InternationalJournalof Managerial Finance, 10(4): 442-452. 